\title{
LINK AND MATCH PROGRAM WITH BUSINESS AND INDUSTRY (DU/DI) AS AN EFFORT FOR PLACEMENT OF GRADUATES AT SMK MUHAMMADIYAH DELANGGU
}

\author{
Uswatun Khasanah \\ Department of Islamic Education, Faculty of Tarbiyah, Institut Islam Mamba'ul 'Ulum Surakarta \\ Sadewa Street No.14, Serengan, Surakarta, Central Java, Indonesia. 57155 \\ Email: uzwa.staimklaten@gmail.com
}

\begin{abstract}
This research is qualitative research with a case study approach. The data sources used were words and actions as well as written sources. The techniques of research subject collection were purposive sampling and snowball sampling. The data collection techniques chosen were observation, interview, documentation, and triangulations. Data validity testing techniques included triangulation of technical resources. The data were analyzed using interactive analysis techniques in the form of data reduction, data presentation, and conclusion drawing/ verification. Based on the research findings, the implementation of the link and match program starts from the preparation/ planning stage, the implementation of the teaching and learning process in schools and the cooperation with the industry, and the evaluation stage. The supporting factor for the link and match is the cooperation between the school and DU/DI. In addition, there are a positive responses from students, parents, DU/DI, and the government. There are wo inhibiting factors of the link and match, namely internal and external factors. The solutions used to overcome the problems that occurred are (a) the school always provides supplies and maximizes the practice unit; (b) the school tries to maximize the existing curriculum with work processes in industry so as not to deviate from the core competencies or basic competencies (KI/KD) determined by the Education Office.
\end{abstract}

Keywords: DU/DI, link and match program, SMK Graduate

\begin{abstract}
Abstrak: Penelitian ini merupakan penelitian kualitatif dengan pendekatan studi kasus. Sumber data yang digunakan adalah kata-kata dan tindakan serta sumber tertulis. Teknik pengumpulan subjek penelitian adalah purposive sampling dan snowball sampling. Teknik pengumpulan data yang dipilih adalah observasi, wawancara, dokumentasi, dan triangulasi. Teknik pengujian keabsahan data meliputi triangulasi sumber daya teknis. Analisis data menggunakan teknik analisis interaktif berupa reduksi data, penyajian data, dan penarikan kesimpulan/verifikasi. Berdasarkan hasil penelitian, pelaksanaan program link and match dimulai dari tahap persiapan/perencanaan, pelaksanaan proses belajar mengajar di sekolah dan kerjasama dengan pihak industri, serta tahap evaluasi. Faktor pendukung link and match tersebut adalah kerjasama antara pihak sekolah dengan DU/DI. Selain itu, respon yang positif dari siswa, orang tua, DU/DI, dan pemerintah. Ada dua faktor penghambat link and match yaitu faktor internal dan eksternal. Solusi yang digunakan untuk mengatasi permasalahan yang terjadi adalah (a) sekolah selalu menyediakan perbekalan dan memaksimalkan unit praktik; (b) sekolah berusaha memaksimalkan kurikulum yang ada dengan proses kerja di industri agar tidak menyimpang dari kompetensi inti atau kompetensi dasar (KI/KD) yang ditetapkan Dinas Pendidikan.
\end{abstract}

Kata Kunci: DU/DI, link and match program, SMK Graduates

\section{Introduction}

One indicator of the success of the Vocational High School is seen from how its graduates or alumni can be absorbed in the working world or continue to higher education. This success does not come by itself, but there needs to be a holistic effort from the school to prepare its students (Dwimawanti et al., 2002). As in the word of Allah QS. At-Tahrim: 6.

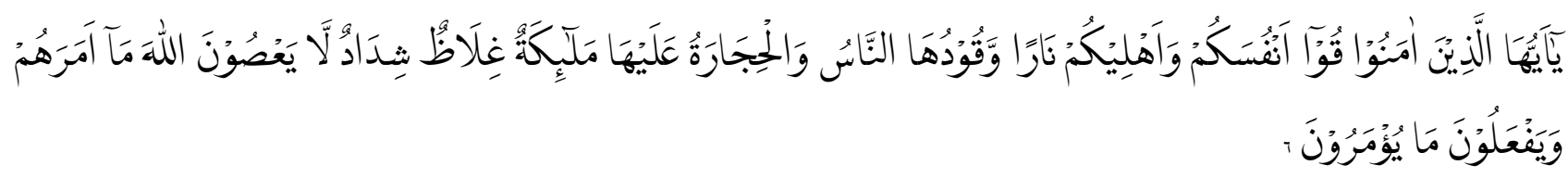

Meaning:

"O you who believe, protect yourself and your family from the fires of hell whose fuel is people and stones; the keeper of angels who are harsh, harsh, and do not disobey Allab towards what He commands them and always do what is ordered". 
The purpose of education is to produce students who have character and are guided by the AlQur'ani. To make human beings with character, students must be directed from an early age to understand the Qur'an by mentoring it; read, study, practice and teach it; this also applies to the hadith. So that with mentadabburi al-Qur'an and Sunnah, it is hoped that students will become children with the personality of the Prophet, namely the person of the Qur'an. The person who solves the problem does not add to the problem. A person who lives and lives in every journey of the times. Noble person like the al-Qur'an.

In addition to preparing students with various aspects of education such as knowledge, skills and attitude to be competent with the chosen study program or expertise competence, it is also necessary to have an institution assigned to provide direction, provide information, about the world of work and to the next level of education in accordance with the chosen study program. This is due to the limitations of students or alumni in accessing the working world and the many competitors of fellow Vocational High School alumni. As stated by Mustaghfirin Amin, Director of Vocational Development, Directorate General of Secondary Education, Ministry of Education and Culture if the Republic of Indonesia in 2014, there were 4.4 million vocational students throughout Indonesia with 1.3 million graduates every year.

One of the government policies for the success of the Vocational School Revitalization program is Regulation of the Minister of Industry (Permenperin) Number 3 of 2017. Philosophically link and match can mean insight into the development of the quality of human resources, the future, quality and excellence, professionalism, added value and efficiency. Link and match involves an interactive process with matched results. Theoretically, link and match refers to the link and match of the competence of graduates from the world of education so that they can be accepted and are in accordance with the needs of the world of work. From this statement, world education must be able to collaborate with all parties related to the world of work, such as industry (Decree of Minister of Manpower and Transmigration of the Republic of Indonesia year 2013 No. 389).

SMK Muhammadiyah Delanggu is a vocational high school in Delanggu City. Through its vision and mission, SMK Muhammadiyah Delanggu wants to produce graduates in accordance with world of work industrial world DU/DI by establishing cooperation in the form of implementing dual system education (PSG), Internship, and Absorption/Distribution of Graduates. When viewed from the target pattern of organizing life skills according to the Ministry of National Education in Syafriadi (2017), vocational education is deemed successful in creating graduates with the following success indicators:

1. The graduates work according to their fields;

2. The maximum graduate grace period is one year after graduating;

3. Minimum absorption of $75 \%$;

4. $5 \%$ of the graduates create job opportunities.

These four indicators can be implemented by SMK Muhammadiyah Delanggu and can be applied in various majors to produce graduates relevant with the job opportunities This can be proven through the Tracer Study ini Table 1.

Table 1. Tracer study of SMK Muhammadiyah Delanggu graduates in 2016/2017 and 2017/2018

\begin{tabular}{|c|c|c|c|c|c|c|c|}
\hline $\begin{array}{c}\text { Year of } \\
\text { Graduation }\end{array}$ & Study Program & $\begin{array}{l}\text { Number } \\
\text { Graduate }\end{array}$ & Linear & $\begin{array}{c}\text { Not } \\
\text { Linear }\end{array}$ & $\begin{array}{c}\text { Own } \\
\text { Business }\end{array}$ & $\begin{array}{l}\text { Continuing } \\
\text { Study }\end{array}$ & Unidentified \\
\hline \multirow[t]{7}{*}{ 2016-2017 } & Accounting & 9 & $55.56 \%$ & $11.11 \%$ & $22.22 \%$ & $11.11 \%$ & $0.0 \%$ \\
\hline & Marketing & 19 & $52.63 \%$ & $15.79 \%$ & $15.79 \%$ & $5.26 \%$ & $10.53 \%$ \\
\hline & $\begin{array}{l}\text { Office } \\
\text { Administration }\end{array}$ & 29 & $51.72 \%$ & $24.14 \%$ & $17.24 \%$ & $0.0 \%$ & $6.90 \%$ \\
\hline & Nursing & 37 & $67.57 \%$ & $5.41 \%$ & $5.41 \%$ & $21.62 \%$ & $0.0 \%$ \\
\hline & Pharmacy & 22 & $90.91 \%$ & $0.0 \%$ & $0.0 \%$ & $9.09 \%$ & $0.0 \%$ \\
\hline & Automotive & 100 & $66.0 \%$ & $17.0 \%$ & $11.00 \%$ & $3.00 \%$ & $3.0 \%$ \\
\hline & $\%$ & 216 & 64.1 & 12.24 & 11.94 & 8.35 & 3.40 \\
\hline \multirow[t]{4}{*}{$2017-2018$} & Accounting & 18 & $100 \%$ & $0.0 \%$ & $0.0 \%$ & $0.0 \%$ & $0.0 \%$ \\
\hline & Marketing & 25 & $88.0 \%$ & $4.00 \%$ & $0.0 \%$ & $8.00 \%$ & $0.0 \%$ \\
\hline & $\begin{array}{l}\text { Office } \\
\text { Administration }\end{array}$ & 29 & $82.76 \%$ & $3.45 \%$ & $6.90 \%$ & $3.45 \%$ & $3.45 \%$ \\
\hline & Nursing & 39 & $84.62 \%$ & $0.0 \%$ & $0.0 \%$ & $15.38 \%$ & $0.0 \%$ \\
\hline
\end{tabular}




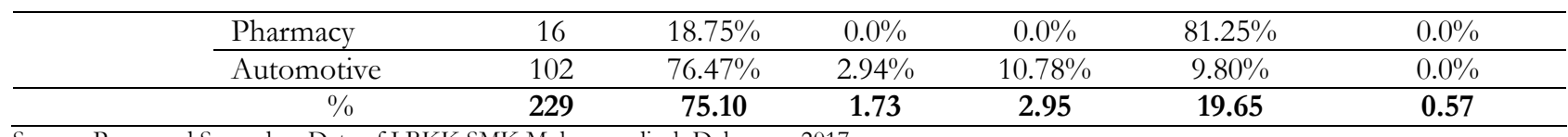

Source: Processed Secondary Data of LBKK SMK Muhammadiyah Delanggu, 2017

These data indicate an increase in particular the distribution of graduates in accordance with their expertise of $64.1 \%$ and non-linear graduates of $12.24 \%$ in 2016 . Then, in 2017 , there are $75.10 \%$ of graduates who are linear with their fields of expertise and $1.73 \%$ are not linear.

\section{Materials and Methods}

A. Research Method and Approach

This research used a qualitative method based on the assumption that the qualitative research places more emphasis on the nature of naturalism, meaning that the reality that appears as the study material in this research, so the object of the research and problems regarding the implementation of the link and match program with the business and industry in SMK Muhammadiyah Delanggu.

The researcher did not provide treatment to the object, so the object was left it is. The research approach used was a case study approach. The strategy used in this research was single embedded (Bungin, 2009). Single means that there is only one scope of the research location i.e. SMK Muhammadiyah Delanggu. Embedded means what is studied is limited to aspects of implementation, starting from planning/preparation of link and match program, program implementation, supporting factors and inhibitors of the link and match as well as solutions used to overcome problems that occur.

\section{B. Data and Data Sources}

Data is a reality or fact in the form of objects, events, writing, or figures that are deliberately collected or recorded through observation or interviews for reasoning or research purposes (Djamal, 2015). Data sources in this research include:

1. Words and Actions

This research used the key informant, namely the Head of the Expertise Program, considering that he could provide information regarding the implementation of the link and match program directly.

2. Written Source

Written sources used in this study include the implementation of the results of the Apprenticeship Evaluation Report from schools, Apprenticeship Training Materials (Training and Implementation of Vocational High School Curriculum 2013), Manual of SMK Muhammadiyah Delanggu Quality, Internship MoU, Internship Journal and Implementation Report from students, Tracer study of graduates from all Expertise Programs (2016/2017, 2017/2018 and 2018/2019), and LSP P3 Retail Competency Test Instruments.

The research subjects were collected using Purposive and Snowball Sampling techniques. Then the researchers chose snowball sampling. There are three data collection techniques chosen in this research: 1. Observation

Based on the research conducted, observations were focused on practicum laboratories for all expertise programs. Observations in this study include students and teachers.

2. Interview

One type of interview that demands more involvement in the informant life is in-depth interview. In-depth interviews are the process of obtaining information using questions and answers while having face to face between the interviewer and the informant with or without using interview guidelines, where the interviewer and the informant are involved in a relatively long social life (Bungin, 2009). The considerations in choosing in-depth interviews are: 1) by using in-depth interview, the topic regarding the implementation of the link and match program with DU/DI can be studied in more detail and in depth, 2) in-depth interview requires clarification from the various parties involved, and 3) there is a directed discussion using open-ended questions. 
The types of document selected in this research are legal documents in the form of internal documents from SMK Muhammadiyah Delanggu, for example Evaluation Report of Internship Implementation from the school, Internship Training Materials, Manual of SMK Muhammadiyah Delanggu Quality, Internship MoU, Internship Journal and Implementation Report from students, Tracer study of graduates (2016/2017, 2017/2018 and 2018/2019), and LSP P3 Retail Competency Test Instruments.

\section{Data Validity Test Technique}

The research on the link and match program was tested using triangulation of sources and techniques.

1. Source Triangulation

Based on the research conducted, the process of data validity testing was done by checking the validity of the data from the informants. After the data were collected, they were then checked, clarified, and the trustworthiness of the data was confirmed to the informant. The data were valid if each informant could provide the same information about the topic being studied.

2. Technical Triangulation

Based on the research conducted, the process of testing the validity of the data were done by checking information collected from the interviews with observations (written in field notes) and documentation collected (written documents and photos of activities/ places visited).

\section{Data Analysis Technique}

In this research, there are three data analysis techniques as follows (Moleong, 2015):

1. Data reduction

The steps taken in the process of reducing data were summarizing, selecting, and focusing matters relating to the implementation of the link and match program in accordance with the formulated problem. This includes the implementation of the link and match program with DU/DI on marketing graduates at SMK Muhammadiyah Delanggu, supporting and inhibiting factors, as well as solutions carried out to overcome the problems that occur.

\section{Data Presentation}

Through this data presentation, the researcher is expected to be able to determine the next strategy in conducting the research. The step taken in the process of presenting data was that the researcher made a transcript of each interview conducted. In addition to making transcripts, the data presentation was done in a narrative form, in the form of a checklist of laboratory observations.

3. Conclusion Drawing/ Verification

The steps taken in the process of drawing conclusions regarding the implementation of the link and match program were highlighting key points, proving with documents collected, and then drawing general conclusions about the implementation of the link and match program with DU/DI on marketing graduates at SMK Muhammadiyah Delanggu, supporting and inhabiting, as well as solutions carried out to overcome the problems that occurred.

\section{Result and Discussion}

Based on the findings of researchers, the link and match program was achieved through teaching and learning in schools and cooperation with industries. Learning has been made referring to $70 \%: 30 \%$, but it is still not maximal. This is indicated by several problems that arise. However, the students admitted having gained many benefits, namely. The students become trained and accustomed. With a lot of knowledge that is very useful for entering the working world, in addition to striving for learning in schools, SMK Muhammadiyah Delanggu also strives for learning that involves industry, including (Thaufan, 2019):

1. Curriculum Synchronization

2. Internship

3. Industry Visit 
4. Production Unit

5. Expertise Competency Test

The five programs are one inseparable unit to support the qualifications of graduates to fit the needs and demands of the DU/DI. Of all the programs, the final determinant of student competence \& qualifications is at Expertise Competency Test (UKK). UKK results show that vocational graduates get "Competent" results. In line with this, based on the research findings, four indicators according to the Ministry of National Education in Syafriadi (2017) Can be applied at SMK Muhammadiyah Delanggu to produce graduates who are in accordance with the job field even though it is not optimal. This can be seen from the data of graduates from various study programs in 2018/2019 obtained from LBKK SMK Muhammadiyah Delanggu in Table 2.

Table 2. Tracer study of SMK Muhammadiyah Delanggu Graduates in 2018/2019

\begin{tabular}{clcccccc}
$\begin{array}{c}\text { Year of } \\
\text { Graduation }\end{array}$ & Study Program & $\begin{array}{c}\text { Number } \\
\text { Graduate }\end{array}$ & Linear & $\begin{array}{c}\text { Not } \\
\text { Linear }\end{array}$ & $\begin{array}{c}\text { Own } \\
\text { Business }\end{array}$ & $\begin{array}{c}\text { Continuing } \\
\text { Study }\end{array}$ & Unidentified \\
\hline $\mathbf{2 0 1 8 - 2 0 1 9}$ & Accounting & 25 & $92.00 \%$ & $0.0 \%$ & $0.0 \%$ & $8.00 \%$ & $0.0 \%$ \\
\cline { 2 - 9 } & Marketing & 35 & $100 \%$ & $0.0 \%$ & $0.0 \%$ & $0.0 \%$ & $0.0 \%$ \\
\cline { 2 - 9 } & $\begin{array}{l}\text { Office } \\
\text { Administration }\end{array}$ & 36 & $77.78 \%$ & $0.0 \%$ & $11.11 \%$ & $8.33 \%$ & $2.78 \%$ \\
& Nursing & 38 & $76.32 \%$ & $0.0 \%$ & $0.00 \%$ & $23.68 \%$ & $0.0 \%$ \\
\cline { 2 - 9 } & Pharmacy & 24 & $20.83 \%$ & $0.0 \%$ & $12.50 \%$ & $29.17 \%$ & $37.50 \%$ \\
\cline { 2 - 9 } & Automotive & 98 & $84.69 \%$ & $2.04 \%$ & $7.14 \%$ & $2.04 \%$ & $4.08 \%$ \\
\hline \multicolumn{1}{c}{$\%$} & $\mathbf{2 5 6}$ & $\mathbf{7 5 . 2 7}$ & $\mathbf{0 . 3 4}$ & $\mathbf{5 . 1 3}$ & $\mathbf{1 1 . 8 7}$ & $\mathbf{7 . 3 9}$ \\
\hline
\end{tabular}

Source: Processed Secondary Data of LBKK, 2019

Based on Table 2, graduates of the study programs in 2018/2019 have obtained relevant jobs by $75.27 \%$. The graduates who chose to open their own business are $5.13 \%$ with the relevant job criteria. There are quite a lot of graduates who have not yet defined their jobs by $7.39 \%$. The total graduates are 256 students. LBKK always recapitulates the graduates who have already got a job or who have not to maximize services in the Special Job Exchange.

\section{Link and Match Program with Business and Industry DU/DI for The Graduates of SMK Muhammadiyah Delanggu}

Link and match are the policy of Ministry of Education of the Republic of Indonesia introduced by Prof. Dr. Ing. Wardiman Djoyonegoro in 1989-1998 serving as Minister of Education and Culture at that time. The concept refers to the link and match of the graduates' competence from the education world in order to be accepted and match the needs of the working world. The link and match program with the business and the industry in graduates of all study programs of SMK Muhammadiyah Delanggu is achieved through the teaching and learning process in schools and the cooperation with industries.

The Learning Process in SMK Muhammadiyah Delanggu is planned to refer to $70 \%$ practice and $30 \%$ theory, but it is still not optimal. It is known that there is no balance between theory and practice, the lack of the teacher's role in the teaching and learning process in the classroom, and the deepening of the material felt by students that is still not optimal. However, the school continues to do its best because in fact the demand of practice tends to be more than theory. In accordance with one of the principles of link and match conveyed by Tilaar in a Listiana's research (2012), the adequate facilities and infrastructure were needed to support the implementation of the research in the field of industry and other practices. In this way, efforts to increase the relevance of educational programs to community needs can be realized so that it will be easier to implement a link and match policy.

Nevertheless, the alumni claim to have benefited from the teaching and learning process for 3 (three) years in their respective majors, namely through the process of teaching and learning in schools, students become trained and accustomed with a lot of knowledge about productive science in accordance with their expertise competencies that are very useful to enter the working world. In addition to seeking learning in schools, SMK Muhammadiyah Delanggu also seeks learning that involves industry. It also relates to one of the principles of link and match, namely the improvement of educational programs. 
Vocational high schools together with DU/DI realize collaborative programs between schools and industries in the form of:

a. Curriculum Synchronization

Curriculum synchronization is one of the partnership programs between the vocational high school and the business and industry. Curriculum synchronization is in the context of curriculum development Based on the findings, curriculum synchronization consists of several stages, including: (1) Planning/Preparation. Curriculum synchronization is a process of synchronizing the existing curriculum of the education office with the needs that exist in the industry at the beginning of the school year by involving DU/DI to schools. DU/DI is involved in synchronization at SMK Muhammadiyah Delanggu. The purpose of synchronization is DU/DI can correct syllabus or curriculum documents to then add the material that is felt to be lacking and needs to be delivered to students; (2) Implementation. In general, the steps for synchronizing the curriculum begin with the drafting of the SK Development Team by the Vice Principal of Curriculum. The task of the development team is to prepare curriculum documents. After the documents are finished, they are then submitted to the committee (including parents' representatives), DU/DI, and supervisors to be validated, checked, and revised; (3) Evaluation. Based on year-to-year evaluations, SMK Muhammadiyah Delanggu has not been able to get the "Very Good" predicate. This is because there are still some problems that have arisen, namely the school claiming to have difficulty adjusting DU/DI needs to existing KI/KD and Ministerial Regulation No. 61 of 2014. In the Permen, there are still some unfulfilled points, one of which is vision and mission. The results of synchronization activities are expected to obtain curriculum results that have high relevance to the competencies needed by the partner institution. By synchronizing curriculum in a planned, programmed and continuous manner, vocational high schools will always produce graduates who link and match with the development in the work environment.

b. Internship

The internship program is arranged and planned together between the school and industry to meet the needs of students and a form of contribution from the working world towards educational development efforts in vocational high schools (Dikdasmen, 2016). Based on the research interviews, internship is a collaborative program that involves the industry by giving students experience to practice directly to DU/DI during certain periods. The stages of organizing internship shown in Table 3.

Table 3. The stages in organizing internship

\begin{tabular}{lll}
\hline No & \multicolumn{1}{c}{ Internship Stages } & \multicolumn{1}{c}{ Remark } \\
\hline 1 & Planning/ Preparation & Industry mapping is a process of KD analysis and learning/work topics \\
1. Industry Mapping & in the expertise package subject to obtain DU/DI data in accordance with \\
2. Time of Implementation & the KD of students and to improve the cooperation between the school \\
3. Internship Briefing & Time of Implementation at DU/DI can be carried out in class XI or class \\
4. Supervisor Determination & XII. Based on the results of the research, the internship in SMK \\
& Muhammadiyah Delanggu is held in class XI Semester 4 for 3 months. \\
& Internship briefing for internship participants is carried out for students \\
& who will carry out internship to provide an understanding of the learning \\
& activities that must be carried out in DU/DI. Internship supervisors consist \\
& of internal school supervisors (Productive Teachers) and external school \\
& supervisors (industry).
\end{tabular}

\footnotetext{
3 Evaluation
} 
c. Industry Visit

Industry visit is a form of the real activity that can be seen by students. They directly visit the industry to see the production process carried out, starting from the pre-production to post-production. d. Production Unit

Production unit is a form of cooperation between the school and industry. The purpose of the production unit is to improve the ability of knowledge, skills, and the formation of work attitudes for students and teachers because they will learn directly in managing their business.

e. Expertise Competency Test

Expertise Competency Test (UKK) is one form of effectiveness of school cooperation with the industry (Yulianto \& Sutrisno, 2014; Ixtiarto \& Sutrisno, 2016). Based on the results of the research, there are several stages of the implementation of UKK shown in Table 4.

Table 4. The stages in the implementation of UKK

\begin{tabular}{lll}
\hline No & \multicolumn{1}{c}{ UKK Stages } & \multicolumn{1}{c}{ Remark } \\
\hline 1 & Planning/ Preparation & UKK is a form of link and match program carried out at SMK \\
& Muhammadiyah Delanggu with reference to competence standards \\
that apply in the industry. The purpose is that the substance of & learning with the vocational curriculum can be achieved with the hope \\
& that student express competencies they master in the form of \\
& performance and carry out actual and natural works based on \\
& applicable competency standards.
\end{tabular}

The five components above, they must complement each other. SMK Muhammadiyah Delanggu tries to maximize the Link and Match Program through several components above to place graduates into DU/DI relevant with their fields. However, it depends on the individual graduate because there are some graduates who are placed in accordance with their competence but refuse for various reasons. The reasons include being not ready to work, not wanting to work outside the city, etc. Figure 1 shows the data collected by researchers through LBKK SMK Muhammadiyah Delanggu from 2016 to 2018/or the last three years.

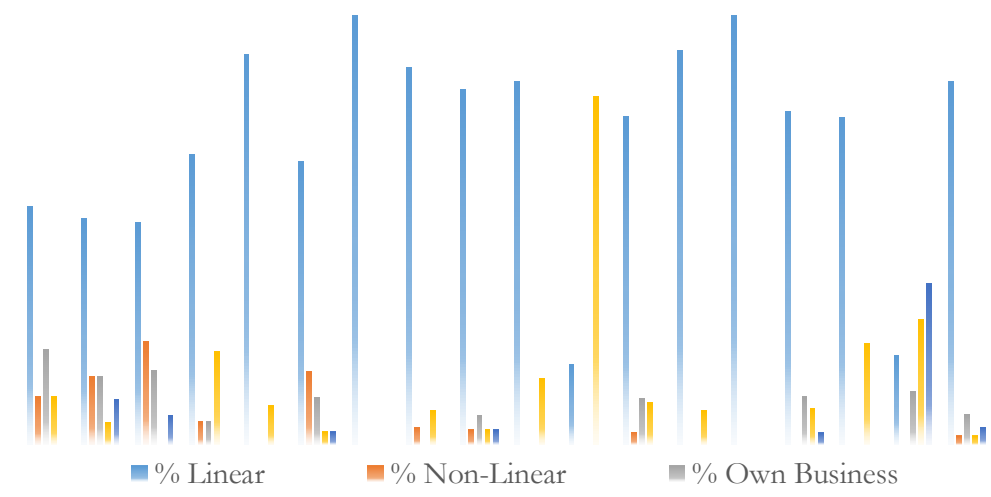

Figure 1. Link and match program (Source: LBKK SMK Muhammadiyah Delanggu) 
Based on the data in Figure 1, in alleviating the link and match program in the vocational high school starting in 2016, the linear distribution of the graduates was $64.1 \%$, non-linear graduates $12.24 \%$, opening their own business $11.94 \%$, continuing study $8.35 \%$ and unidentified $3.40 \%$ of 216 students. Then in 2017 , the graduates who worked linearly was $75.10 \%$, non-linearly $1.73 \%$, opening their own business $2.95 \%$, continuing their study $19.65 \%$ and not identified $0.57 \%$. In 2018 , the data obtained included $75.27 \%$ of the graduates working linearly, $0.34 \%$ non-linearly, 5.13\% opening their own business, $11.87 \%$ continuing their study, and $7.39 \%$ unidentified. From year to year, the Link and Match Program at SMK Muhammadiyah Delanggu always tries to improve the performance of LBKK in order to channel graduates according to their fields and maximize their services. Then, LBKK also holds many MoUs or collaborate with DU/DI and hold seminars related to "Work Motivation for Graduates."

\section{Supporting and Inhibiting Factors of Link and Match with DU/DI in SMK Muhammadiyah Delanggu}

Based on the research findings, there are always problems in every activity, either supporting activities or inhibiting activities. The following are the supporting factors of the link and match in general, namely: (a) Cooperation between the school and DU/DI, both from Curriculum Synchronization, Internship, Industry Visit, Production Unit, and Expertise Competency Test; and (b) The responses from students, parents, DU/DI, and government are positive.

The inhibiting factors of the link and match in general are as follows:

a. Internal factors.

The internal factors of the students are, for instance, their low enthusiasm related to the implementation of internship. For the Production Unit, there are errors in bookkeeping when the store practice (Production Unit) and the lack of confidence, accuracy, and focus during the implementation of internship and UKK. For the school, it has not been able to empower the store to its full potential.

b. External factors

In connection with the implementation of Synchronization Curriculum, the school finds it difficult to adjust the needs with the demands of DU/DI. In addition, in conducting industry visits, the school has not been able to carry out the demand from Mirota regarding the amount of goods that must be purchased because they cannot force students to buy the items promoted.

\section{The Solution Carried Out to Overcome the Problems of the Link and Match Program at SMK Muhammadiyah Delanggu}

The various problems that occur in SMK Muhammadiyah Delanggu, the school has negotiated to provide solutions to the problems. The solutions include the following;

a. Internal factors

To overcome the problems from internal factors when viewed from the perspective of students, the school always tries to give briefing, both for knowledge and motivation. In terms of maximizing production units, the school maximizes the Laboratories, Cooperative Units, Automotive Workshops, etc. Also, the school is trying to collaborate with DU/DI so that in the distribution of graduates there are many choices in choosing jobs.

b. External factors

To overcome the problems of external factors when viewed from the problem of Curriculum Synchronization, the school tries to maximize the existing curriculum to be adapted to industrial work processes. Meanwhile, when viewed from the problem of industry visits, the school has conducted an evaluation and will not conduct an industry visit that is not relevant with the expertise program of each major

\section{Conclusion}

SMK Muhammadiyah Delanggu is a private school in Delanggu City. The link and match program that has been carried out and evaluated every year is still lacking. However, with this lack, there is a continuing evaluation like the placement program for graduates at SMK Muhammadiyah Delanggu every 
year trying to channel according to their fields of expertise although there are some graduates who have worked not relevant with their expertise. The programs carried out in the school in the form of 5 programs include: 1) Curriculum Synchronization; 2) Internship; 3) Industry Visits; 4) Production Units; and 5) Expertise Competency Test is. Those programs are inseparable from the supporting and inhibiting factors which are then addressed with policies that produce solutions to each problem that exists.

\section{References}

Bungin, M. B. 2009. "Penelitian Kualitatif: Komunikasi, Ekonomi, Kebijakan Publik, dan Ilmu Sosial Lainnya, Edisi Pertama." Jakarta: Kencana.

Data Lembaga Bursa Kerja Khusus (LBKK) SMK Muhammadiyah Delanggu, 2019.

Departemen Agama Republik Indonesia. 2007. “Al-Qur'an dan Terjemahnya Special for Women.” Bandung: Syaamil AlQur'an.

Directorate of Vocational High School Development, Directorate of Primary and Secondary Education. 2015. "Rencana Strategis Direktorat Pembinaan SMK Periode 2015-2019." Jakarta: Ministry of Education and Culture.

Djamal, M. 2015. "Paradigma Penelitian Kualitatif, Edisi Revisi." Yogyakarta: Pustaka Pelajar.

Dwimawanti, I. H., Fathurrohman., \& Marom, A. 2002. "Evaluasi Program Link and Match di Sekolah Menengah Kejuruan Kota Semarang." Research Report. Semarang: Universitas Diponegoro.

Interview with the Head of LBKK (H.Thaufan HSW, S.Ag., M.Pd) on Monday, August 9, 2019.

Ixtiarto, B., and B. Sutrisno. 2016. "Kemitraan Sekolah Menengah Kejuruan Dengan Dunia Usaha dan Dunia Industri: Kajian aspek Pengelolaan pada SMK Muhammadiyah 2 Wuryantoro.” Jurnal Pendidikan Ilmu Sosial 26(1): 57-69.

Listiana. 2012. "Analisis Pelaksanaan Program Sistem Ganda (PSG) dalam Mempersiapkan Siswa Memasuki Dunia Kerja (Studi Kasus di SMK 5 Pancasila Wonogiri Program Keahlian Administrasi Perkantoran Tahun Diklat 2011/2012.” Thesis. Surakarta: Faculty of Teacher Training and Education, Universitas Sebelas Maret.

Minister of Manpower and Transmigration of the Republic of Indonesia. 2013. Ministerial Decree No. 389 of 2013 about "Penetapan Standar Kompetensi Kerja Nasional Indonesia Kategori Jasa Profesional, Ilmiah dan Teknis, Golongan Pokok Kegiatan Kantor Pusat dan Konsultasi Manajemen, Golongan Konsultasi Manajemen, Sub Golongan Konsultasi Manajemen Area Kerja Pemasaran.” Jakarta: Minister of Manpower and Transmigration of the Republic of Indonesia.

Moleong, L.J. 2015. "Metodologi Penelitian Kualitatif, Edisi Revisi." Bandung: PT Remaja Rosdakarya.

Syafriadi, M. 2017. Permasalahan SMK dan Solusinya. Retrieved on February 16, 2018, from https://msyafriadi.wordpress.com/2017/03/15/permasalahan-smk-solusinya/. 